\title{
RISK FACTORS FOR DEVELOPING DIASTOLIC DYSFUNCTION IN NONALCOHOLIC STEATOHEPATITIS
}

Article history:

Received 6 March 2019

Received in revised form 31 March 2019

Accepted 10 April 2019

\section{S.N. Jadhav, V.G. Radchenko, P.V. Seliverstov, S.I. Sitkin}

Department of internal medicine and nephrology, North-western state medical university named after I.I. Mechnikov, Saint Petersburg, Russia. swapjul@hotmail.com

\section{N TRODUCTION}

In the last 20 years, nonalcoholic fatty liver disease (NAFLD) has become the leading cause of chronic liver disease worldwide, primarily as a result of the epidemic of metabolic syndrome. NAFLD is strongly associated with insul in resistance, glucose intolerance, and dyslipidemia and is currently regarded as the liver manifestation of the metabolic syndrome. Mortality in NAFLD is associated with cardiovascular disease, not with liver failure. Nonalcoholic steatohepatitis (NASH) is a type of NAFLD. NASH suggest about inflammation in liver cell damage.

\section{O B J E C T | V E}

To assess the risk factors in nonalcoholic steatohepatitis, which can lead to the development of diastolic dysfunction.

\section{RESEARCH DESIGN AND METHODS}

In cohort study, we enrolled 140 patients with nonalcoholic steatohepatitis (NASH) in results of metabolic syndrome. All patient was non-alcoholic and without any concomitant heart disease. All patients undergone biochemical blood testing, ultrasonography and echocardiography. NASH was diagnosed by ultrasonography and biochemical blood analysis. All patients were excluded for viral hepatitis (B, C, D).

\section{RESULTS}

According to our echocardiography data we found occurrence of diastolic dysfunction in NASH is $60 \%$. Diastolic dysfunction was more often in male than female. Patient with grade 3 diastolic dysfunction was symptomatic in terms of dyspnea, palpitation and intolerance to moderate to heavy physical activity. HOMA-IR index was raised in $96 \%$ patients with NASH. In presence diastolic dysfunction in NASH observed that high level of the HOMA-IR
$(6.06 \pm 0.7, \mathrm{p}<0,05)$, fasting glucose $(6,30 \pm 1.91 \mathrm{mmol} / \mathrm{l}$, $\mathrm{p}<0,05)$, ALT $(43,61 \pm 0,422 \mathrm{u} / \mathrm{l}, \mathrm{p}<0,05)$, Alkaline phosphatase $(143,59 \pm 2,848 \mathrm{u} / \mathrm{l}, \mathrm{p}<0,001)$, Gamma-glutamyl transferase $(82,22 \pm 1,178 \mathrm{u} / 1$, $\mathrm{p}<0,05)$ cholesterol $(5,99 \pm 1,324 \mathrm{mmol} / \mathrm{l}, \mathrm{p}<0,05)$, triglyceride $(2,91 \pm 0,258 \mathrm{mmol} / 1, \mathrm{p}<0,05), \mathrm{LDL}$ $(1,68 \pm 0,492 \mathrm{mmol} / \mathrm{l}, \mathrm{p}<0,05)$ compare to $\mathrm{pa}-$ tients without presence of diastolic dysfunction in NASH. In patient with NASH had high level of uric acid. In presence of diastolic dysfunction in NASH $56.90 \%$ of patients had high level of uric acid (male 427,60 $\pm 12,344 \mathrm{mmol} / \mathrm{l}, \mathrm{p}<0,05$, female $365,43 \pm 10,344 \mathrm{mmol} / \mathrm{l}, \mathrm{p}<0,05)$ compare those $\mathrm{pa}$ tients without diastolic dysfunction in NASH.

\section{CONCLUSIONS}

Our study data showed that high level of HOMA-IR, LFT(ALT, alkaline phosphatase, gammaglutamyl transferase), dyslipidemia, uric acid are associated with diastolic dysfunction in NASH. Probably these factors lead to development of cardiovascular disease in NASH.

\section{REFERENCES}

1. Anstee QM Targher G, Day CP Progression of NAFLD to diabetes mellitus, cardiovascular disease or cirrhosis. //Nat Rev Gastroenterol Hepatol - 2013. No. 6 - Vol. 10. - P. 330-344.

2. Berg A.H. Combs T.P., Du X., BrownleE M., SCHERER P.E. The adipocyte-secreted protein ACRP30 enhances hepatic insulin action// Nat. Med. - 2001 No. - 7. - P. 947-953.

3. BonOw RO UdELSON JE. Left ventricular diastolic dysfunction as a cause of congestive heart failure. Mechanisms and management// Ann Intern Med. 1992. No. 6 - vol. 117. - P. 502-510.

4. Boudina $S$ Dale Abel E Diabetic cardiomyopathy revisited //Circulation - 2007. - No. 115. P. 3213-3223.

5. Brutsaert D Sys SU, Gillebert TC. Diastolic failure: pathophysiology and therapeutic implications. // J Am Coll Cardiol. - 1993. - No. 22 - P. 318-325.

6. Byrne CD TARgher G. NAFLD: A multisystem disease.// J Hepatol. - 2015. - No. 65. - P. S47-S64.

7. Cregler Ll Georgiou D, Sosa I.J. Left ventricular diastolic dysfunction in patients with congestive 
heart failure. // Natl Med Assoc. - 1991. - No. 1 - vol. 83. - P. 49-52.

8. Diamant M Lamb HJ, Groeneveld Y et al

Diastolic dysfunction is associated with altered myocardial metabolism in asymptomatic normotensive patients with well-controlled type 2 diabetes mellitus.// J Am Coll Cardiol. - 2003. - vol. 42. - P. 328-335.

9. Duckworth WC Hamel FG, Peavy DE. Hepatic metabolism of insulin.// Am J Med. - 1988. - vol. 85. - P. $71-6$.

10. Evandro T. M. Antonio J. L. J. Understanding Asymptomatic Diastolic Dysfunction in Clinical Practice. // Arq Bras Cardiol. - 2013. - No.1 - vol. 100. - P. 94-101.
11. Fraser A, Harris R, Sattar N, Ebrahim $S$, Davey SMith G, Lawlor DA. Alanine aminotransferase, gamma-glutamyltransferase, and incident diabetes: the British Women's Heart and Health Study and meta-analysis. // Diabetes Care. - 2009. - vol. 32. - P. 741-50.

12. S.N. Jadhav, V. G. Radchenko, P. V. SeliverSTOV, S. I. SITKIN Predictors diastolic dysfunction of LV in patients with NAFLD / Профилактическая медицина.(Preventional medicine) - 2018 . - 4 : No. 69. - P. 190-194. 